\title{
Size and vigor of Anadenanthera colubrina (Vell.) Brenan seeds harvested in Caatinga areas ${ }^{1}$
}

\author{
Jaciara de Souza Bispo ${ }^{2}$, Danielle Carolina Campos da Costa ${ }^{2}$, \\ Samara Elizabeth Vieira Gomes ${ }^{2}$, Gilmara Moreira de Oliveira ${ }^{3}$, \\ Janete Rodrigues Matias ${ }^{4}$, Renata Conduru Ribeiro ${ }^{5}$, Bárbara França Dantas ${ }^{5^{*}}$
}

\begin{abstract}
Angico is a species found in several environments in Brazil, with several applications. It is used in the timber industry and mainly in folk medicine. In order to verify a variation in the biometric characteristics and the quality of seeds from different mother-plants in different harvesting years, the following variables were studied: moisture content, diameter, density, electrical conductivity, fresh and dry matter of seedlings, germination percentage and kinetics, in a completely randomized design with a $2 \times 3$ factorial arrangement (lots $\mathrm{x}$ size). The obtained results showed that angico seeds from different lots showed different physiological quality, possibly due to the climate variations to which mother-plants were submitted in the different years. Seed size directly interferes with seedling growth under both controlled and greenhouse conditions, and it can be used as a vigor indicator for angico seeds.
\end{abstract}

Index terms: physiological quality, biometrics, Fabaceae, angico.

\section{Tamanho e vigor de sementes de Anadenanthera colubrina (Vell.) Brenan colhidas em área de Caatinga}

\begin{abstract}
RESUMO - O angico é uma espécie encontrada em diversos ambientes no Brasil, e apresenta diversas aplicações, sendo utilizado pela indústria madeireira e principalmente na medicina popular. Buscando-se verificar a variação quanto a caracteres biométricos e qualidade de sementes provenientes de diferentes matrizes em diferentes anos de coleta, desenvolveram-se ensaios após o beneficiamento das sementes, em que foram avaliados: teor de água, diâmetro, densidade, condutividade elétrica, matéria fresca e seca de plântulas, porcentagem e cinética de germinação, em delineamento inteiramente casualizado com esquema fatorial $2 \times 3$ (lotes $\mathrm{x}$ tamanho). Os resultados obtidos demostraram que sementes de angico de diferentes lotes apresentam qualidade fisiológica distinta, possivelmente pelas variações do clima as quais as árvores matrizes foram submetidas nos diferentes anos de coleta. O tamanho das sementes interfere diretamente no crescimento de plântulas tanto em condições controladas, quanto em casa de vegetação, podendo ser utilizado como indicativo de vigor para sementes de angico.
\end{abstract}

Termos para indexação: qualidade fisiológica, biometria, Fabaceae, angico.

\section{Introduction}

The Caatinga presents a heterogeneous vegetation. It is a biome with at least 932 species registered for the region, of which 380 are endemic, with 20 occurrence genera in this biome alone (MMA, 2002), as well as being a biome that is restricted to the Brazilian territory. Human actions are responsible for a

${ }^{1}$ Submitted on $12 / 20 / 2016$. Accepted for publication on 10/18/2017.

${ }^{2}$ Departamento de Tecnologia e Ciências Sociais, Universidade do Estado da Bahia, 48905-680 - Juazeiro, BA, Brasil.

${ }^{3}$ Departamento de Biologia, Universidade Estadual de Feira de Santana, 44036-900 - Feira de Santana, BA, Brasil.
45.62\% loss of its original vegetation (MMA, 2011).

In the state of Pernambuco, only 62,924.85 ha of all its territory present conservation units of the Caatinga biome (Gariglio et al., 2010). Seed storage and the production of native seedlings are alternatives that can contribute to the maintenance and conservation of the biome.

In Brazil, the flora of the semi-arid region is exploited by

${ }^{4}$ Universidade Federal Rural do Semiárido, 59625-900 - Mossoró , RN, Brasil.

${ }^{5}$ Embrapa Semiárido, Caixa Postal 23, 56302-970 - Petrolina, PE, Brasil.

*Corresponding author< barbara.dantas@embrapa.br> 
local communities for various purposes, including obtaining natural drugs (Gomes et al., 2008). Among the plants with phytotherapeutic potential, it is possible to highlight Anadenanthera colubrina (Vell.) BRENAN (Fabaceae), commonly known as angico (Weber et al., 2011), with natural occurrence in semideciduous seasonal forests and mixed rain forests (Rego et al., 2007). In popular medicine, it is commonly used for lung diseases, through decoctions, juices (Silva et al., 2012 b), as well as through the surface of the stem, in addition to the narcotic properties of its fruits (Agra et al., 2007). Besides its application in the timber industry, civil construction, hydraulic installations, crossties and boards, it can also be used to decorate squares and parks, and in recovering degraded areas (Lorenzi, 2009).

Anadenanthera colubrina represents one of the main leguminous plants exploited on rural properties in the countryside of the Brazilian Northeast, with $19 \%$ of the local population exploiting it to build rural facilities (Silva et al., 2012 a). It is considered a potential species to be used in intercropping with species of economic interest, such as Manihot esculenta Crantz. (Martinotto et al., 2012).

This species is classified as initial secondary in recovery vegetation. It presents high annual seed production, and its autochory dispersal occurs at the end of the dry period, generally between August and September, being the main regeneration form through the germination of its seeds (Carvalho, 2003).

The importance of biometry, both of fruits and seeds, consists in the possibility of observing the phenotypic variability between lots, due to the climatic conditions in which mother-plants were exposed throughout the year (Corrêa et al., 2008). For many species, it indicates their physiological quality (Santos et al., 2012).

Some researches were developed in order to evaluate the influence of size on the physiological quality of seeds of Caesalpinia leiostachya (BENTH.) DUCKE (Biruel et al.,
2010), Tamarindus indica L. (Pereira et al., 2008), Hymenaea stigonocarpa var. stigonocarpa Mart. ex Hayne (Pereira et al., 2011), Plinia jabuticaba (Vell.) Berg. (Wagner Júnior et al., 2011), Artocarpus heterophyllus Lam. (Silva et al., 2010), Copernicia prunifera (Mill.) H.E. Moore. (Reis et al., 2010), Melanoxylon brauna Schott. (Flores et al., 2014), Brosimum gaudichaudii TRÉCUL (Faria et al., 2013) and Sideroxylon obtusifolium (Roem. \& Schult.) Penn. (Silva, 2015) seeds, demonstrating a straight relation between seed size and vigor.

During a seed production season, there may be variations in seed size and performance, since they are characteristics directly influenced by climate, soil fertility, seed maturity and sanity (Marcos-Filho, 2015).

The purpose of this research was to evaluate the influence of different harvests and sizes on the physiological quality of A. colubrina seeds collected within the same tree population in a Caatinga area, in two subsequent years.

\section{Material and Methods}

Anadenanthera colubrina seeds were collected in the district of Lagoa Grande, community of Jutaí - Pernambuco state, Brazil, at the coordinates $37^{\circ} 18^{\prime} 3^{\prime \prime}$ 'W and $90^{\circ} 52^{\prime} 92^{\prime}$ 'S $\mathrm{S}$, in July 2012 and 2013. Precipitation and evaporation mapping of the harvesting region were carried out by metheorological station of Embrapa-Semiárido/Bebedouro (Table 1); in the harvesting years, temperatures presented an annual average of $27^{\circ} \mathrm{C}$ and an average annual relative humidity of 55\% (EMBRAPA, 2016).

Fruit follicles of $A$. colubrina were harvested directly from randomized selected mother-plants with the help of a metal cutter and canvas on the ground, considering the brown coloration of the pods as the maturity point (Matias et al., 2014 ). Then, they were taken to the laboratory for processing (removal of branches, damaged seeds, leaves and other impurities). After that, intact seeds were stored for two years (2012 seed lot) and one year (2013 seed lot) in cloth

Table 1. Average monthly and annual precipitation $(\mathrm{mm})$ and evaporation $(\mathrm{mm})$ information collected from Embrapa Semiárido - Bebedouro Metheorological Station (Petrolina - Pernambuco state).

\begin{tabular}{|c|c|c|c|c|c|c|c|c|c|c|c|c|c|}
\hline \multicolumn{14}{|c|}{ Average precipitation (mm) } \\
\hline Year & Jan & Feb & Mar & Apr & May & Jun & Jul & Aug & Sep & Oct & Nov & Dec & $\bar{x}$ \\
\hline 2013 & 70.8 & 0.0 & 4.2 & 37.8 & 7.3 & 4.4 & 9.5 & 1.9 & 1.1 & 0.8 & 25.5 & 184.5 & 347.8 \\
\hline 2012 & 6.3 & 61.5 & 4.0 & 0.0 & 14.3 & 5.7 & 0.9 & 2.4 & 0.0 & 0.0 & 11.9 & 0.2 & 107.2 \\
\hline 2011 & 12.2 & 19.9 & 73.3 & 89.8 & 68.2 & 2.0 & 5.7 & 21.1 & 0.0 & 0.6 & 14.8 & 27.9 & 335.5 \\
\hline \multicolumn{14}{|c|}{ Average evaporation (mm) } \\
\hline Year & Jan & Feb & Mar & Apr & May & Jun & Jul & Aug & Sep & Oct & Nov & Dec & $\bar{x}$ \\
\hline 2013 & 8.1 & 9.3 & 9.3 & 7.9 & 6.7 & 6.8 & 6.8 & 8.1 & 9.9 & 10.1 & 8.6 & 7.0 & 8.2 \\
\hline 2012 & 8.9 & 7.3 & 8.2 & 8.0 & 6.8 & 7.0 & 7.0 & 7.9 & 9.1 & 9.8 & 8.3 & 9.8 & 8.2 \\
\hline 2011 & 6.8 & 6.9 & 5.9 & 6.2 & 5.1 & 5.7 & 6.5 & 7.5 & 9.0 & 8.1 & 7.9 & 8.6 & 7.0 \\
\hline
\end{tabular}


bags at $10{ }^{\circ} \mathrm{C} \pm 3{ }^{\circ} \mathrm{C}$ and $40 \% \pm 10 \%$ relative humidity, until the beginning of the tests.

Seeds from each lot (2012 and 2013) were separated into three sizes, in relation to the diameter: small (up to $0.9 \mathrm{~cm}$ ), medium $(0.91-1.10 \mathrm{~cm})$ and large (above $1.10 \mathrm{~cm})$. Tests were conducted in a completely randomized design with a 2 × 3 (lot $\mathrm{x}$ size) factorial arrangement, with four replications of 25 seeds per treatment. Averages were compared by Tukey's test at $5 \%$ and data were submitted to the Pearson correlation test (r).

\section{Biometry and initial evaluations}

Due to the small amount of seeds available for this work, the use of four replicates with 25 seeds was standardized for all the initial evaluations and physiological quality tests, except for seed density and seedling growth.

A. colubrina seeds are round and flattened, with less than $1.0 \mathrm{~mm}$ of thickness; therefore, as a measure for seed size, the diameter (Ø) of seeds was evaluated with a millimeter ruler. The 100-seed weight was evaluated by weighing four replications of 25 seeds for each size of each lot on a precision scale $(0.0001 \mathrm{~g})$. To evaluate seed density (D), a $10 \mathrm{~mL}$ becker was used, and filled with seeds until its maximum volumetric capacity, then weighed $(\mathrm{g})$; four $10 \mathrm{~mL}$ replications were performed. The moisture content (MC) of $A$. colubrina seeds was determined by oven method, at $105 \pm 3{ }^{\circ} \mathrm{C}$ for 24 hours (Brasil, 2009).

\section{Physiological Quality}

Germination (G\%): seeds were distributed on germitest paper rolls, moistened with distilled water in the proportion of 2.5 times the weight of the paper. The rolls were packed in plastic bags to minimize water evaporation from the paper, and incubated in BOD-type germination chambers at the constant temperature of $25 \pm 1^{\circ} \mathrm{C}$ for 10 days (Brasil, 2013). At the end of this tests, mean germination time (MGT) (Labouriau, 1983), mean germination rate (MGR) (Labouriau and Valadares, 1976), germination speed index (GSI) (Maguire, 1962) were calculated. On the $4^{\text {th }}$ day after incubation, the first count of normal seedlings (FCG) was performed, and at the end, on the $10^{\text {th }}$ day of the test, the final count of normal seedlings (FING) was performed. It was also evaluated the shoot (SG) and root (RG) growth, shoot (SFM) and root (RFM) fresh matter, shoot (SDM) and root (RDM) dry matter of 10 seedlings from each replication (Nakagawa, 1999).

Electrical conductivity (EC): four replications of 25 seeds were used. The samples were initially weighed and $75 \mathrm{~mL}$ of distilled water were added; after that, seeds were incubated at a constant temperature of $25 \pm 1{ }^{\circ} \mathrm{C}$ for 24 hours. After this interval, the electrical conductivity was measured $\left(\mu \mathrm{S} . \mathrm{cm}^{-1} \cdot \mathrm{g}^{-1}\right)$
(Vieira and Carvalho, 1994).

Cold test (CT): four replications of 25 seeds per lot were used on a germitest paper roll moistened with distilled water, at an amount equivalent to 2.5 times the weight of the dried substrate. The rolls were placed in plastic bags and incubated at $10 \pm 1{ }^{\circ} \mathrm{C}$, for seven days. After this period, rolls were removed and placed at $25 \pm 1{ }^{\circ} \mathrm{C}$ for 10 days, performing the first count of normal seedlings (FCNS) on the $4^{\text {th }}$ day of incubation and the final count of normal seedlings (CT) on the $10^{\text {th }}$ day. Data were expressed as percentage (\%) (adapted from Vieira and Carvalho, 1994).

Emergence test: was conducted in a greenhouse under $50 \%$ shading, in polyethylene trays with sand and daily water supply (0.416 mL.tray $\left.{ }^{-1}\right)$ through a hand irrigator. Sowing was performed with vertical seed deposition at a $1 \mathrm{~cm}$ depth. Evaluations were carried out as previously mentioned: emergence percentage in daily count for 14 days (E\%), mean emergence time (MET), mean emergence rate (MER), emergence speed index (ESI). At the end of the test, shoot (SGE) and root (RGE) growth were evaluated, and data were

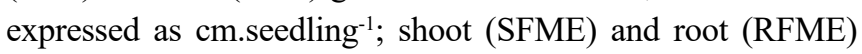
fresh matter, shoot (SDME) and root (RDME) dry matter, being the data expressed in grams $(\mathrm{g})$.

\section{Results and Discussion}

\section{Biometry and initial evaluations}

Seeds generally presented increasing 100-seed weight, diameter and density, according to visually observed size increase. There was, however, an interaction between lots from different crops and seed size, resulting in a similar density between medium and large seeds from the 2013 crop (Table 2). A. colubrina seeds presented about $6.5 \%$ of moisture content; this was similar for all lots, except for small seeds collected in 2012, which presented a lower moisture content (6.27\%) than the others (Table 2).

Evaluating the weight of seeds from different harvests, a higher weight was observed for seeds from the 2013 lot in relation to the seeds collected in 2012. However, 2013 seeds presented smaller average diameter and density than those from 2012 (Table 2). Water unavailability during the transfer phase of assimilated compounds between motherplants and seedlings may determine mainly a decrease in seed size, weight and physiological potential (Zaman-Allah et al., 2011). Thus, possibly, the maturation of A. colubrina seeds was damaged by the region's low rainfall index in 2012 (Table 1). 
Table 2. 100-seed weight, water content, density and diameter of A. colubrina seeds with different sizes and collected in 2012 and 2013 at Jutaí - Pernambuco state.

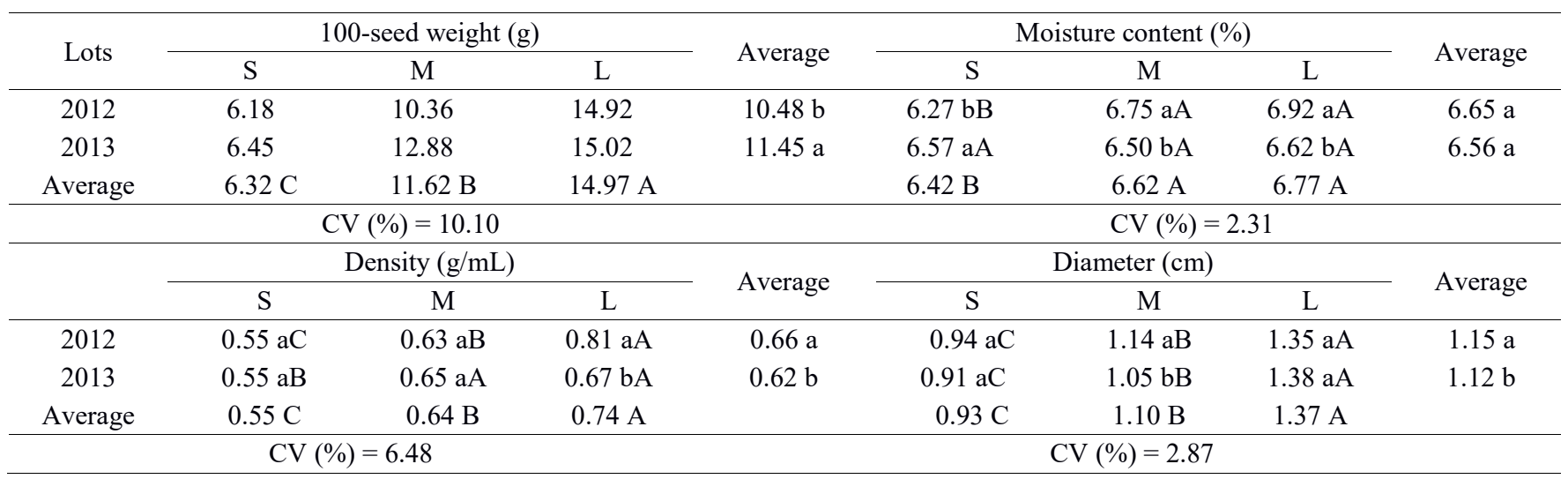

Averages followed by the same letter, lowercase in the columns and upper case in the lines, do not differ from each other by Tukey's test at $5 \%$.

\section{Physiological quality}

Germination $(\mathrm{G} \%)$ of $A$. Colubrina seeds of different sizes and lots did not result in statistical differences for the studied interaction; however, it was observed that, on an average, seeds from the 2012 lot presented higher germination percentage (76\%) in relation to the 2013 lot (57\%) (Table 3). This negative effect on germination is possibly also a result of the low average annual precipitation in the region, associated with high evaporation in 2012 (Table 1); this may have caused the formation of less vigorous seeds. The 2013 lot presented higher mean germination time (1.93 days), whereas the highest mean germination rate was observed for the 2012 lot (0.82 radicle.day $^{-1}$ ) (Table 3 ). The germination speed index of small, medium and large seeds from 2012 did not differ statistically, and it was observed that seeds classified as small and medium showed higher GSI in relation to large seeds, as well as the 2012 lot in relation to the 2013 lot (Table 3).

Large Syzygium malaccense (L.) Merryl et Perry seeds resulted in a higher mean GSI (Costa et al., 2006), similar to a study conducted with Melanoxylon brauna Schott., Flores et al. (2014). However, in this work, the interaction of large seeds from the 2013 lot expressed lower GSI, possibly due to the fact that the low annual precipitation of this lot's year promoted a deficit in the translocation of photoassimilated compounds between the plant and the seed, providing inadequate supply conditions for the embryo (Table 3). Seeds from the Caatinga show great variation in size, color and presence of connected structures, with great influence of the environmental conditions during their production (Meiado et al., 2012; Dantas et al., 2014). These variations may interfere in the physiological quality of seeds (Oliveira et al., 2009).

The size of angico seeds did not interfere with the first and the final counts of normal seedlings of germination test. However, the 2012 lot presented a higher percentage of seedling formation than the 2013 lot (Table 3). The seed size did not interfere with the shoot length (SG) of seedlings coming from 2013 seeds. However, seeds collected in 2012 presented a proportional SG to the seed size. Larger seed promoted greater accumulation of shoot fresh (SFM) and dry (SDM) matter (Table 4).

There was no interaction for the root growth variables. However, the 2012 lot, as well as large seeds, promoted on an average greater development of the roots, when compared to seedlings from the 2013 lot (Table 4).

Medium sized Hymenaea stigonocarpa var. stigonocarpa seeds present larger primary root emission capacity when compared to large seeds (Pereira et al., 2011). In relation to the root length, medium-sized seeds of Eugenia uniflora L. presented larger growth in relation to small seeds (Antunes et al., 2012).

Possibly, the low rainfall at the collection site during the formation of 2013 seeds interfered in the transfer of photosimilated compounds between plant and seed. The environmental and nutritional conditions of the mother-plants directly affect the seed mass by interfering with the size and physiological potential of seeds (Marcos-Filho, 2015).

In the cold test (Table 5), there was no significant interaction for the studied factors; however, it was observed that the 2013 lot presented higher seedling formation than what was observed for the 2012 lot. Possibly, the slow imbibition allowed a better repair of the cell structures, allowing greater efficiency for the process of seedling formation.

According to Marcos-Filho (2015), suboptimal temperatures predispose the loss of cellular solutes, mainly sugars, due to the disorganization of the cellular membranes 
Table 3. Germination (G), mean germination rate (MGR), mean germination time (MGT), germination speed index (GSI), first count (FCG) and final count of normal seedlings (FING) originated from seeds of $A$. colubrina of different sizes and collected in 2012 and 2013 in Jutaí-Pernambuco state.

\begin{tabular}{|c|c|c|c|c|c|c|c|c|}
\hline \multirow{2}{*}{ Lots } & \multicolumn{3}{|c|}{ G (\% radicle emission) } & \multirow{2}{*}{ Average } & \multicolumn{3}{|c|}{ MGT (dias) } & \multirow{2}{*}{ Average } \\
\hline & $\mathrm{S}$ & $\mathrm{M}$ & $\mathrm{L}$ & & $\mathrm{S}$ & $\mathrm{M}$ & $\mathrm{L}$ & \\
\hline 2012 & 73.00 & 79.00 & 77.00 & $76.33 \mathrm{a}$ & 1.14 & 1.27 & 1.29 & $1.23 \mathrm{~b}$ \\
\hline 2013 & 53.00 & 68.00 & 50.00 & $57.00 \mathrm{~b}$ & 1.73 & 1.70 & 2.34 & $1.93 \mathrm{a}$ \\
\hline Average & $63.00 \mathrm{~A}$ & $73.50 \mathrm{~A}$ & $63.50 \mathrm{~A}$ & & $1.44 \mathrm{~A}$ & $1.49 \mathrm{~A}$ & $1.82 \mathrm{~A}$ & \\
\hline \multicolumn{4}{|c|}{$\mathrm{CV}(\%)=14.36$} & \multicolumn{5}{|c|}{$\mathrm{CV}(\%)=22.26$} \\
\hline & \multicolumn{3}{|c|}{ MGR (radicle.day ${ }^{-1}$ ) } & \multirow{2}{*}{ Average } & \multicolumn{3}{|c|}{ GSI } & \multirow{2}{*}{ Average } \\
\hline & $\mathrm{S}$ & $\mathrm{M}$ & $\mathrm{L}$ & & $\mathrm{S}$ & $\mathrm{M}$ & $\mathrm{L}$ & \\
\hline 2012 & 0.88 & 0.78 & 0.80 & $0.82 \mathrm{a}$ & $17.70 \mathrm{aA}$ & $18.00 \mathrm{aA}$ & $17.83 \mathrm{aA}$ & $17.85 \mathrm{a}$ \\
\hline 2013 & 0.62 & 0.60 & 0.43 & $0.55 \mathrm{~b}$ & $9.33 \mathrm{bAB}$ & $12.72 \mathrm{bA}$ & $7.45 \mathrm{bB}$ & $9.84 \mathrm{~b}$ \\
\hline Average & $0.75 \mathrm{~A}$ & $0.69 \mathrm{~A}$ & $0.61 \mathrm{~A}$ & & $13.52 \mathrm{AB}$ & $15.36 \mathrm{~A}$ & $12.64 \mathrm{~B}$ & \\
\hline \multicolumn{4}{|c|}{$\mathrm{CV}(\%)=19.35$} & \multicolumn{5}{|c|}{$\mathrm{CV}(\%)=13.85$} \\
\hline \multirow{2}{*}{ Lots } & \multicolumn{3}{|c|}{ FCG $(\%)$} & \multirow{2}{*}{ Average } & \multicolumn{3}{|c|}{ FING (\%) } & \multirow{2}{*}{ Average } \\
\hline & $\mathrm{S}$ & $\mathrm{M}$ & $\mathrm{L}$ & & $\mathrm{P}$ & $\mathrm{M}$ & $\mathrm{G}$ & \\
\hline 2012 & $49.00 \mathrm{aA}$ & $46.00 \mathrm{aA}$ & $56.00 \mathrm{aA}$ & $50.33 \mathrm{a}$ & 67.00 & 69.00 & 65.00 & $67.00 \mathrm{a}$ \\
\hline 2013 & $19.00 \mathrm{bAB}$ & $26.00 \mathrm{bA}$ & $5.00 \mathrm{bB}$ & $16.66 \mathrm{~b}$ & 35.00 & 47.00 & 35.00 & $39.00 \mathrm{~b}$ \\
\hline Average & $34.00 \mathrm{~A}$ & $36.00 \mathrm{~A}$ & $30.50 \mathrm{~A}$ & & $51.00 \mathrm{~A}$ & $58.00 \mathrm{~A}$ & $50.00 \mathrm{~A}$ & \\
\hline \multicolumn{4}{|c|}{$\mathrm{CV}(\%)=29.88$} & \multicolumn{5}{|c|}{$\mathrm{CV}(\%)=18.87$} \\
\hline
\end{tabular}

Averages followed by the same letter, lowercase in the columns and upper case in the lines, do not differ from each other by Tukey's test at $5 \%$.

Table 4. Shoot (SG) and root (RG) growth, shoot (SFM) and root (RFM) fresh matter, aerial shoot (SDM) and root (RDM) dry matter of A. colubrina seedlings originated from seeds of A. colubrina of different sizes and collected in 2012 and 2013 in Jutaí - Pernambuco state.

\begin{tabular}{|c|c|c|c|c|c|c|c|c|}
\hline \multirow{2}{*}{ Lots } & \multicolumn{3}{|c|}{$\mathrm{SG}(\mathrm{cm})$} & \multirow{2}{*}{ Average } & \multicolumn{3}{|c|}{$\mathrm{RG}(\mathrm{cm})$} & \multirow{2}{*}{ Average } \\
\hline & $\mathrm{S}$ & $\mathrm{M}$ & $\mathrm{L}$ & & $\mathrm{S}$ & $\mathrm{M}$ & 1 & \\
\hline 2012 & $5.15 \mathrm{bC}$ & $5.71 \mathrm{aB}$ & $7.05 \mathrm{aA}$ & $5.97 \mathrm{a}$ & 7.55 & 8.92 & 11.13 & $9.20 \mathrm{a}$ \\
\hline 2013 & $5.75 \mathrm{aA}$ & $6.12 \mathrm{aA}$ & $5.63 \mathrm{bA}$ & $5.83 \mathrm{a}$ & 5.36 & 6.48 & 6.77 & $6.20 \mathrm{~b}$ \\
\hline Average & $5.45 \mathrm{C}$ & $5.91 \mathrm{~B}$ & $6.34 \mathrm{~A}$ & & $6.45 \mathrm{~B}$ & $7.70 \mathrm{AB}$ & $8.95 \mathrm{~A}$ & \\
\hline \multicolumn{4}{|c|}{$\mathrm{CV}(\%)=4.73$} & \multicolumn{5}{|c|}{$\mathrm{CV}(\%)=17.93$} \\
\hline \multirow{2}{*}{ Lots } & \multicolumn{3}{|c|}{ SFM $(\mathrm{g})$} & \multirow{2}{*}{ Average } & \multicolumn{3}{|c|}{ RFM (g) } & \multirow{2}{*}{ Average } \\
\hline & $\mathrm{S}$ & $\mathrm{M}$ & $\mathrm{L}$ & & $\mathrm{S}$ & $\mathrm{M}$ & $\mathrm{L}$ & \\
\hline 2012 & $0.61 \mathrm{aB}$ & $0.80 \mathrm{aB}$ & $1.17 \mathrm{aA}$ & $0.86 \mathrm{a}$ & 0.27 & 0.50 & 0.51 & $0.42 \mathrm{a}$ \\
\hline 2013 & $0.44 \mathrm{bB}$ & $0.84 \mathrm{aA}$ & $0.88 \mathrm{bA}$ & $0.72 \mathrm{~b}$ & 0.15 & 0.34 & 0.43 & $0.31 \mathrm{~b}$ \\
\hline Average & $0.53 \mathrm{C}$ & $0.82 \mathrm{~B}$ & $1.02 \mathrm{~A}$ & & $0.21 \mathrm{~B}$ & $0.42 \mathrm{~A}$ & $0.47 \mathrm{~A}$ & \\
\hline \multicolumn{4}{|c|}{$\mathrm{CV}(\%)=13.82$} & \multicolumn{5}{|c|}{$\mathrm{CV}(\%)=24.48$} \\
\hline & \multicolumn{3}{|c|}{$\mathrm{SDM}(\mathrm{g})$} & \multirow{2}{*}{ Average } & \multicolumn{3}{|c|}{ RDM (g) } & \multirow{2}{*}{ Average } \\
\hline & $\mathrm{S}$ & $\mathrm{M}$ & $\mathrm{L}$ & & $\mathrm{S}$ & $\mathrm{M}$ & $\mathrm{L}$ & \\
\hline 2012 & $0.10 \mathrm{aB}$ & $0.13 \mathrm{aB}$ & $0.20 \mathrm{aA}$ & $0.14 \mathrm{a}$ & 0.07 & 0.11 & 0.14 & $0.11 \mathrm{a}$ \\
\hline 2013 & $0.08 \mathrm{aB}$ & $0.13 \mathrm{aA}$ & $0.13 \mathrm{bA}$ & $0.12 \mathrm{~b}$ & 0.04 & 0.08 & 0.10 & $0.07 \mathrm{~b}$ \\
\hline Average & $0.09 \mathrm{C}$ & $0.13 \mathrm{~B}$ & $0.17 \mathrm{~A}$ & & $0.06 \mathrm{~B}$ & $0.09 \mathrm{~A}$ & $0.12 \mathrm{~A}$ & \\
\hline \multicolumn{4}{|c|}{$\mathrm{CV}(\%)=13.88$} & \multicolumn{5}{|c|}{$\mathrm{CV}(\%)=25.62$} \\
\hline
\end{tabular}

Averages followed by the same letter, lowercase in the columns and upper case in the lines, do not differ among themselves by Tukey's test at $5 \%$.

system. In these conditions, the water quantity becomes more important, because the water contained in seeds can promote the formation of ice crystals, causing mechanical ruptures in the cell wall and in the membrane system, promoting cell disaggregation and consequent loss of seed viability (Roberts, 1973), leading to injuries and causing the loss of the germination capacity (Hellmann et al., 2006).

The electrical conductivity (EC) of medium and large 
seeds leachate resulted was higher when compared to small seeds (Table 5). The EC test showed that $A$. colubrina seeds maintained the integrity of the cell membrane system (Table 5). Thus, it was not efficient, because it did not show differences in the physiological quality of lots from different harvests.

The emergence percentage $(\mathrm{E} \%)$ of medium seeds from 2012 was statistically similar to what was observed for seeds classified as large in the 2013 lot. It was also observed that medium and large seeds promoted on an average higher $\mathrm{E} \%$ in relation to seeds classified as small (Table 6).

In Dimocarpos longan Lour, the emergence percentage and emergence speed index were not affected by the size of seeds (Oliveira et al., 2005); in Eugenia uniflora L., it was observed that, 90 days after sowing, medium seeds presented a higher emergence percentage (Antunes et al., 2012). This result was similar to that observed in a research with Eugenia uniflora L., in which medium and large seeds resulted in a higher emergence percentage, besides having a longer root length (Klein et al., 2008). However, for the emergence speed index (ESI), no statistical difference was observed, as observed in this study (Table 6). The other evaluated variables did not present a statistically significant difference. Results show that seeds collected in 2013 and with larger size influence the final emergence percentage and their time interval to emerge, possibly due to the greater amount of reserves. Large seeds establish themselves faster in the field, efficiently enduring the adverse conditions of the environment (Pádua et al., 2010).

Larger seeds are generally better nourished during their

Table 5. First count (FCC) and final count (CT) of normal seedlings submitted to cold test $\left(10{ }^{\circ} \mathrm{C}\right)$ for 10 days, and electric conductivity (EC) originated from seeds of A. colubrina of different sizes and collected in 2012 and 2013 in Jutaí Pernambuco state.

\begin{tabular}{|c|c|c|c|c|c|c|c|c|}
\hline \multirow{2}{*}{ Lots } & \multicolumn{3}{|c|}{$\mathrm{FCC}(\%)$} & \multirow{2}{*}{ Average } & \multicolumn{3}{|c|}{ CT $(\%)$} & \multirow{2}{*}{ Average } \\
\hline & $\mathrm{S}$ & $\mathrm{M}$ & $\mathrm{L}$ & & $\mathrm{S}$ & $\mathrm{M}$ & $\mathrm{L}$ & \\
\hline 2012 & 7.00 & 15.00 & 8.00 & $10.00 \mathrm{~b}$ & 8.00 & 15.00 & 17.00 & $13.33 \mathrm{~b}$ \\
\hline 2013 & 19.00 & 39.00 & 33.00 & $30.33 \mathrm{a}$ & 21.00 & 38.00 & 34.00 & $31.00 \mathrm{a}$ \\
\hline Average & $13.00 \mathrm{~A}$ & $27.00 \mathrm{~A}$ & $20.50 \mathrm{~A}$ & & $14.50 \mathrm{~A}$ & $26.50 \mathrm{~A}$ & $25.00 \mathrm{~A}$ & \\
\hline \multicolumn{4}{|c|}{$\mathrm{CV}(\%)=32.48$} & \multicolumn{5}{|c|}{$\mathrm{CV}(\%)=25.31$} \\
\hline \multicolumn{9}{|c|}{$\mathrm{EC}\left(\mu \mathrm{S} \cdot \mathrm{cm}^{-1} \cdot \mathrm{g}^{-1}\right)$} \\
\hline \multirow{2}{*}{\multicolumn{2}{|c|}{ Lots }} & \multicolumn{5}{|c|}{ Size } & \multirow{2}{*}{\multicolumn{2}{|c|}{ Averages }} \\
\hline & & \multicolumn{2}{|l|}{$\mathrm{S}$} & $\mathrm{M}$ & \multicolumn{2}{|c|}{$\mathrm{L}$} & & \\
\hline \multicolumn{2}{|c|}{ Lot 2012} & 930 & & 1.270 & \multicolumn{2}{|c|}{1.410} & \multicolumn{2}{|r|}{$1.210 \mathrm{a}$} \\
\hline \multicolumn{2}{|c|}{ Lot 2013} & 810 & & 1.120 & & 10 & \multicolumn{2}{|r|}{$1.080 \mathrm{a}$} \\
\hline \multicolumn{2}{|c|}{ Average } & $870 \mathrm{~B}$ & & $1.200 \mathrm{~A}$ & \multicolumn{2}{|c|}{$1.360 \mathrm{~A}$} & & \\
\hline
\end{tabular}

Averages followed by the same letter, lowercase in the columns and upper case in the lines, do not differ among themselves by Tukey's test at $5 \%$.

Table 6. Emergence (E\%), mean emergence rate (MER), mean emergence time (MET) and emergence speed index (ESI) originated from seeds of A. colubrina of different sizes and collected in 2012 and 2013 in Jutaí - Pernambuco state, submitted to emergence test in washed sand in a greenhouse with $50 \%$ shading for 10 days.

\begin{tabular}{|c|c|c|c|c|c|c|c|c|}
\hline \multirow{2}{*}{ Lots } & \multicolumn{3}{|c|}{$\mathrm{E} \%$} & \multirow{2}{*}{ Average } & \multicolumn{3}{|c|}{ MET (dias) } & \multirow{2}{*}{ Average } \\
\hline & $\mathrm{S}$ & $\mathrm{M}$ & $\mathrm{L}$ & & $\mathrm{S}$ & $\mathrm{M}$ & $\mathrm{L}$ & \\
\hline 2012 & $15.97 \mathrm{bB}$ & $29.86 \mathrm{aA}$ & $29.16 \mathrm{bA}$ & $25.00 \mathrm{~b}$ & 5.06 & 4.24 & 5.24 & $4.85 \mathrm{a}$ \\
\hline 2013 & $36.80 \mathrm{aAB}$ & $31.25 \mathrm{aB}$ & $47.91 \mathrm{aA}$ & $38.65 \mathrm{a}$ & 4.82 & 4.91 & 4.78 & $4.84 \mathrm{a}$ \\
\hline Average & $26.38 \mathrm{~B}$ & $30.55 \mathrm{AB}$ & $38.54 \mathrm{~A}$ & & $4.94 \mathrm{~A}$ & $4.58 \mathrm{~A}$ & $5.01 \mathrm{~A}$ & \\
\hline \multicolumn{4}{|c|}{$\mathrm{CV}(\%)=20.02$} & \multicolumn{5}{|c|}{$\mathrm{CV}(\%)=13.55$} \\
\hline & \multicolumn{3}{|c|}{ MER (seedlings.day ${ }^{-1}$ ) } & \multirow{2}{*}{ Average } & \multicolumn{3}{|c|}{ ESI } & \multirow{2}{*}{ Average } \\
\hline & $\mathrm{S}$ & $\mathrm{M}$ & $\mathrm{L}$ & & $\mathrm{S}$ & $\mathrm{M}$ & $\mathrm{L}$ & \\
\hline 2012 & $1.24 \mathrm{bB}$ & $2.90 \mathrm{aA}$ & $2.12 \mathrm{bA}$ & $2.08 \mathrm{~b}$ & 0.20 & 0.25 & 0.19 & $0.21 \mathrm{a}$ \\
\hline 2013 & $2.97 \mathrm{aB}$ & $2.40 \mathrm{aB}$ & $3.82 \mathrm{aA}$ & $3.06 \mathrm{a}$ & 0.20 & 0.20 & 0.21 & $0.20 \mathrm{a}$ \\
\hline Average & $2.10 \mathrm{~A}$ & $2.65 \mathrm{~A}$ & $2.97 \mathrm{~A}$ & & $0.20 \mathrm{~A}$ & $0.22 \mathrm{~A}$ & $0.20 \mathrm{~A}$ & \\
\hline \multicolumn{4}{|c|}{$\mathrm{CV}(\%)=27.64$} & \multicolumn{5}{|c|}{$\mathrm{CV}(\%)=17.94$} \\
\hline
\end{tabular}

Averages followed by the same letter, lowercase in the columns and upper case in the lines, do not differ among themselves by Tukey's test at $5 \%$. 
development, having well-formed embryos and with greater amount of reserve substances; consequently, they are more vigorous (Carvalho and Nakagawa, 2012).

The shoot growth (SG) of seedlings originated from the emergence test showed that small and large seeds from the 2012 lot responded in a statistically similar way to larger seeds from the 2013 lot. On average, large seeds promoted greater SG, as well as what was observed for seeds from the 2012 lot in relation to the 2013 lot (Table 7). Smaller seeds, when presenting less amount of reserves, can result in lower seedling emergence and development when compared to seedlings originated from larger seeds (Oliveira et al., 2005).

Analyzing the correlations between the variables, one can observe that the harvest year correlated significantly in a negative way, moderately and strongly, with germination (-0.694), GSI (-0.870), FCG (-0.825) and FING (-0.824). Possibly, the low precipitation of 2013, compared to 2012, as well as the poor distribution of the rains since the flowering period (Nov - Feb), resulted in lower seed vigor for the 2013 lot (Table 1). The occurrence of high temperatures, a characteristic of the semi-arid region, during the maturation of seeds promotes the reduction in the translocation of photoassimilates, especially in periods with low rainfall indices (Marcos-Filho, 2015).

Properties that are pertinent to seed size correlated significantly, between strong $(>0.8)$ and moderate $(0.6-0.79)$
(Table 8). Although the size of $A$. colubrina seeds does not correlate with their viability ( $\mathrm{G} \%$ ), it is observed that the size correlates positively with the growth of seedlings (SG, SDM, RDM, SDME, RDME), presenting a direct relation with their vigor (Tabela 8 ).

Germination $(\mathrm{G} \%)$ correlates positively and moderately with root growth (RG), and this can be explained by the fact that, during germination, the root is generally the first structure to be emitted, having a crucial role in the establishment process of the seedling in the environment (Oliveira and Pereira, 2014).

Emergence(E\%) had a significant correlation, negative and moderate, with G\%, GSI, FCG and FING. The physiological quality of seeds is routinely evaluated by the germination test, but it provides favorable conditions for the process, which allows the lot to express its maximum germination in this condition (Martins et al., 2002). However, these results are not always confirmed on the field, especially when the environmental conditions deviate from the appropriate ones (Mendes et al., 2010).

During the period of the experiment in a greenhouse (Sep Oct), the average climatic conditions were $26.9^{\circ} \mathrm{C} \pm 1{ }^{\circ} \mathrm{C}$, rainfall $0.76 \mathrm{~mm}$ and evaporation of $9.7 \mathrm{~mm}$ (EMBRAPA, 2016). Despite the daily water supply, the high evaporation rate of the environment during the test was high when compared to the water supply $\left(0.833\right.$ L.tray $\left.^{-1}\right)$, which possibly affected the emergence of the seedlings. Low water availability, as well as limiting

Table 7. Shoot (SGE) and root (RGE) growth, shoot (SFME) and root (RFME) fresh matter, shoot (SDME) and root (RDME) dry matter of seedlings originated from seeds of A. colubrina of different sizes and collected in 2012 and 2013 in Jutaí - Pernambuco state, submitted to emergence test in washed sand, in a greenhouse with $50 \%$ shading for 10 days.

\begin{tabular}{|c|c|c|c|c|c|c|c|c|}
\hline \multirow{2}{*}{ Lots } & \multicolumn{3}{|c|}{$\mathrm{SGE}(\mathrm{cm})$} & \multirow{2}{*}{ Average } & \multicolumn{3}{|c|}{ RGE (cm) } & \multirow{2}{*}{ Average } \\
\hline & $\mathrm{S}$ & $\mathrm{M}$ & $\mathrm{L}$ & & $\mathrm{S}$ & $\mathrm{M}$ & $\mathrm{L}$ & \\
\hline 2012 & $4.04 \mathrm{aA}$ & $3.29 \mathrm{aB}$ & $3.73 \mathrm{aAB}$ & $3.69 \mathrm{a}$ & 8.54 & 11.02 & 10.00 & $9.85 \mathrm{a}$ \\
\hline 2013 & $2.61 \mathrm{bB}$ & $3.06 \mathrm{aB}$ & $3.82 \mathrm{aA}$ & $3.16 \mathrm{~b}$ & 9.08 & 8.98 & 10.13 & $9.39 \mathrm{a}$ \\
\hline Average & $3.33 \mathrm{~B}$ & $3.17 \mathrm{~B}$ & $3.78 \mathrm{~A}$ & & $8.81 \mathrm{~A}$ & $10.00 \mathrm{~A}$ & $10.06 \mathrm{~A}$ & \\
\hline \multicolumn{4}{|c|}{$\mathrm{CV}(\%)=9.79$} & \multicolumn{5}{|c|}{$\mathrm{CV}(\%)=13.26$} \\
\hline \multirow{2}{*}{ Lots } & \multicolumn{3}{|c|}{ SFME $(\mathrm{g})$} & \multirow{2}{*}{ Average } & \multicolumn{3}{|c|}{ RFME (g) } & \multirow{2}{*}{ Average } \\
\hline & $\mathrm{S}$ & M & $\mathrm{L}$ & & $\mathrm{S}$ & M & $\mathrm{L}$ & \\
\hline 2012 & $0.36 \mathrm{bB}$ & $1.21 \mathrm{aA}$ & $1.13 \mathrm{bA}$ & $0.90 \mathrm{~b}$ & $0.31 \mathrm{bB}$ & $1.21 \mathrm{aA}$ & $1.21 \mathrm{aA}$ & $0.91 \mathrm{a}$ \\
\hline 2013 & $0.75 \mathrm{aC}$ & $1.29 \mathrm{aB}$ & $1.81 \mathrm{aA}$ & $1.28 \mathrm{a}$ & $0.76 \mathrm{aB}$ & $0.64 \mathrm{bB}$ & $1.19 \mathrm{aA}$ & $0.86 \mathrm{a}$ \\
\hline Average & $0.56 \mathrm{C}$ & $1.25 \mathrm{~B}$ & $1.47 \mathrm{~A}$ & & $0.53 \mathrm{C}$ & $0.92 \mathrm{~B}$ & $1.20 \mathrm{~A}$ & \\
\hline \multicolumn{4}{|c|}{$\mathrm{CV}(\%)=13.44$} & \multicolumn{5}{|c|}{$\mathrm{CV}(\%)=20.90$} \\
\hline & \multicolumn{3}{|c|}{ SDME $(g)$} & \multirow{2}{*}{ Average } & \multicolumn{3}{|c|}{ RDME (g) } & \multirow{2}{*}{ Average } \\
\hline & $\mathrm{S}$ & $\mathrm{M}$ & $\mathrm{L}$ & & $\mathrm{S}$ & M & L & \\
\hline 2012 & $0.11 \mathrm{bB}$ & $0.38 \mathrm{aA}$ & $0.36 \mathrm{bA}$ & $0.29 \mathrm{~b}$ & $0.06 \mathrm{bB}$ & $0.17 \mathrm{aA}$ & $0.17 \mathrm{aA}$ & $0.13 \mathrm{a}$ \\
\hline 2013 & $0.25 \mathrm{aC}$ & $0.42 \mathrm{aB}$ & $0.62 \mathrm{aA}$ & $0.43 \mathrm{a}$ & $0.12 \mathrm{aB}$ & $0.13 \mathrm{aB}$ & $0.19 \mathrm{aA}$ & $0.15 \mathrm{a}$ \\
\hline Average & $0.18 \mathrm{C}$ & $0.40 \mathrm{~B}$ & $0.49 \mathrm{~A}$ & & $0.09 \mathrm{~B}$ & $0.15 \mathrm{~A}$ & $0.18 \mathrm{~A}$ & \\
\hline
\end{tabular}

Averages followed by the same letter, lowercase in the columns and upper case in the lines, do not differ among themselves by Tukey's test at $5 \%$. 
Table 8. Pearson correlation coefficients between variables about physical and physiological characteristics of $A$. colubrina with different sizes and collected in 2012 and 2013 in Jutaí - Pernambuco state.

\begin{tabular}{|c|c|c|c|c|c|c|c|c|c|}
\hline & $\mathrm{S}$ & W100 & $\mathrm{MC}$ & $\mathrm{D}$ & $\varnothing$ & $\mathrm{G} \%$ & GSI & FCG & FING \\
\hline Year & 0.00 & 0.12853 & -0.16949 & -0.20723 & -0.07825 & $-0.69455^{*}$ & $-0.87012 *$ & $-0.82503^{*}$ & $-0.82448 *$ \\
\hline $\mathrm{S}$ & & $0.93919^{*}$ & $0.59032 *$ & $0.81932 *$ & $0.96824 *$ & 0.02985 & -0.07761 & -0.03125 & -0.02404 \\
\hline W100 & & & $0.49668 *$ & $0.73264 *$ & $0.86885^{*}$ & 0.00987 & -0.16191 & -0.10138 & -0.11466 \\
\hline $\mathrm{MC}$ & & & & $0.62475^{*}$ & $0.55134 *$ & 0.10485 & 0.13888 & 0.29128 & 0.11514 \\
\hline $\mathrm{D}$ & & & & & $0.75401 *$ & 0.21328 & 0.22331 & 0.3126 & 0.17611 \\
\hline$\varnothing$ & & & & & & 0.01838 & -0.079 & -0.02775 & -0.01054 \\
\hline $\mathrm{G} \%$ & & & & & & & $0.8504^{*}$ & $0.69056^{*}$ & $0.81448^{*}$ \\
\hline GSI & & & & & & & & $0.91108 *$ & $0.93325^{*}$ \\
\hline FCG & & & & & & & & & $0.84903 *$ \\
\hline \multicolumn{10}{|l|}{ FINCNS } \\
\hline & SG & RG & SDM & RDM & $\mathrm{CT}$ & $\mathrm{EC}$ & $\mathrm{E} \%$ & SDME & RDME \\
\hline Year & -0.10511 & $-0.74616^{*}$ & -0.34648 & $-0.45824 *$ & $0.61649 *$ & -0.23917 & $0.61948^{*}$ & $0.44761^{*}$ & 0.11928 \\
\hline $\mathrm{S}$ & $0.57528^{*}$ & 0.24288 & $0.76111^{*}$ & $0.68134 *$ & 0.31341 & $0.7704 *$ & $0.45008^{*}$ & $0.77802 *$ & $0.69508^{*}$ \\
\hline W100 & $0.51906^{*}$ & 0.16414 & $0.66922 *$ & $0.56595^{*}$ & $0.45551^{*}$ & $0.72589 *$ & $0.40594 *$ & $0.74665^{*}$ & $0.59457^{*}$ \\
\hline $\mathrm{MC}$ & $0.56426^{*}$ & $0.45507^{*}$ & $0.60681^{*}$ & $0.61031^{*}$ & 0.0225 & $0.62636^{*}$ & 0.259 & 0.36283 & $0.52078^{*}$ \\
\hline $\mathrm{D}$ & $0.83830 *$ & $0.51414 *$ & $0.86072 *$ & $0.67815^{*}$ & 0.02967 & $0.58187^{*}$ & 0.17027 & $0.4527^{*}$ & $0.51362 *$ \\
\hline$\varnothing$ & $0.47439 *$ & 0.24779 & $0.68786^{*}$ & $0.65482 *$ & 0.21991 & $0.75799 *$ & $0.45603 *$ & $0.72835^{*}$ & $0.65537 *$ \\
\hline G\% & 0.13857 & $0.63261 *$ & 0.35768 & $0.44767 *$ & -0.30742 & 0.30516 & $-0.53926^{*}$ & -0.16775 & 0.07466 \\
\hline GSI & 0.19051 & $0.76936^{*}$ & 0.38876 & $0.48767 *$ & $-0.44349 *$ & 0.20049 & $-0.68534 *$ & $-0.41 *$ & -0.12397 \\
\hline FCG & 0.33297 & $0.81469 *$ & $0.40607 *$ & $0.5018^{*}$ & $-0.54068 *$ & 0.21614 & $-0.59861 *$ & $-0.45329 *$ & -0.15543 \\
\hline FING & 0.12342 & $0.69810 *$ & 0.39720 & $0.55594 *$ & $-0.42814 *$ & 0.23331 & $-0.53362 *$ & -0.30513 & -0.00616 \\
\hline SG & & $0.54549 *$ & $0.78052 *$ & $0.49186^{*}$ & -0.01475 & 0.37261 & 0.13085 & 0.2766 & $0.44132 *$ \\
\hline $\mathrm{RG}$ & & & $0.67261 *$ & $0.69779 *$ & -0.2897 & 0.34584 & $-0.42975^{*}$ & -0.20762 & 0.13672 \\
\hline SDM & & & & $0.83666^{*}$ & 0.14701 & $0.58867 *$ & 0.06327 & 0.39609 & $0.5819 *$ \\
\hline $\mathrm{RDM}$ & & & & & 0.05832 & $0.6027^{*}$ & 0.00532 & 0.36904 & $0.5669^{*}$ \\
\hline $\mathrm{CT}$ & & & & & & 0.1462 & 0.37824 & $0.54438 *$ & 0.28395 \\
\hline $\mathrm{EC}$ & & & & & & & 0.26817 & $0.56589 *$ & $0.52138^{*}$ \\
\hline E\% & & & & & & & & $0.74746^{*}$ & $0.58823 *$ \\
\hline SDME & & & & & & & & & $0.80415^{*}$ \\
\hline
\end{tabular}

S: size; W100: 100-seed weight; MC: moisture content; D: density; Ø: diameter; G\%: germination percentage; GSI: germination speed index; FCG: first count of normal germination test seedlings; FING: final count of normal germination test seedlings; SG: shoot growth of normal seedlings from the germination test; RG: root growth of normal seedlings from the germination test; SDM: shoot dry mass from the germination test; RDM: root dry matter of normal seedlings from the test of germination; CT: final count of normal seedlings from the cold test; EC: electrical conductivity test; E\%: substrate emergence; ERI: emergence rate index; SDME: shoot dry matter of emergence test seedlings; RDME: root dry matter of the emergence test.

Dark green - strong correlation between variables, light green - medium correlation between variables; yellow - weak correlation between variables.

imbibition, speed and germination percentage, reduces plant growth by decreasing cell expansion (Bewley et al., 2012). Even moderate increases in air temperature or decreases in soil water availability are responsible for decreased plant growth and productivity (Pádua et al., 2009; Vile et al., 2012).

Despite the fact that size (S) did not present any correlation with the variables G\%, FCG and FING, it presented a positive correlation with SG, SDM, RDM, SDME and RDME. Larger seeds in a single species are potentially more vigorous than smaller and less dense ones, and they originate more developed seedlings (Faria et al., 2013), as observed in a study with Sideroxylon obtusifolium (Roem. \& Schult.) Penn. (Silva, 2015) and Clitoria fairchildiana R. Howard (Silva and Carvalho, 2008).

\section{Conclusions}

The classification of $A$. colubrina seeds through size can be adopted as a criterion to obtain seedlings with greater vigor, since larger seeds are generally more vigorous.

The environmental conditions directly influence the physiological quality of $A$. colubrina seeds harvested from the same population.

\section{References}

AGRA, M.D.F.; FREITAS, P.F.D.; BARBOSA FILHO, J.M. Synopsis of the plants known as medicinal and poisonous in Northeast of Brazil. Revista Brasileira de Farmacognosia, v.17, n.1, p.114-140, 2007. http://www.scielo.br/pdf/rbfar/v17n1/a21v17n1.pdf 
ANTUNES, L.E.C.; PICOLOTTO, L.; VIGNOLO, G.K.; GONÇALVES, M.A. Influência do substrato, tamanho de sementes e maturação de frutos na formação de mudas de pitangueira. Revista Brasileira de Fruticultura, v.34, n.4, p.1216-1223, 2012. http:// www.scielo.br/pdf/rbf/v34n4/31.pdf

BEWLEY, J.D.; BRADFORD, K.; HILHORST, H. Seeds: physiology of development, germination and dormancy. Springer Science \& Business Media, 2012. 392 p.

BIRUEL, R.P.; PAULA, R.C.D.; AGUIAR, I.B.D. Germinação de sementes de Caesalpinia leiostachya (Benth.) Ducke (pau-ferro) classificadas pelo tamanho e pela forma. Revista Árvore, v.34, n.2, p.197-204, 2010. http://www.scielo.br/pdf/rarv/v34n2/v34n2a01.pdf

BRASIL. Ministério da AGSIcultura, Pecuária e Abastecimento. Instruções para análises de sementes florestais Brasília, DF, 2013. 98p. http://www.scielo.br/scielo.php?script=sci_nlinks\&pid=S2317$1537201500010004000007 \& \operatorname{lng}=$ en

BRASIL. Ministério da AGSIcultura, Pecuária e Abastecimento. Regras para análise de sementes. Ministério da AGSIcultura, Pecuária e Abastecimento. Secretaria de Defesa Agropecuária. Brasília, DF: MAPA/ACS, 2009. 395p. http://www.aGSIcultura.gov. br/arq_editor/file/2946_regras_analise_sementes.pdf.

CARVALHO, N.M.; NAKAGAWA, J. Sementes: ciência, tecnologia e produção. 5.ed. Jaboticabal: FUNEP, 2012. 590p.

CARVALHO, P.E.R. Espécies florestais brasileiras: recomendações silviculturais, potencialidades e uso da madeira. Brasília: EMBRAPA. Informações Tecnológicas, Colombo, EMPRAPACNPF, 2003. 103p.

CORREAA, G.C.; NAVES, R.B.; ROCHA, M.R.; CHAVES, L.J.; BORGES, J.D. Determinações físicas em frutos e sementes de baru (Dipteryx alata Vog.), cajuzinho (Anacardium othonianum Rizz.) e pequi (Caryocar brasiliense Camb.) visando melhoramento genético. Bioscience Journal, v.24, n.4, p.42-47, 2008. http://www. seer.ufu.br/index.php/biosciencejournal/article/viewArticle/6628

COSTA, R.S.; OLIVEIRA, I.V.D.M.; MÔRO, F.V.; MARTINS, A.B.G. Aspectos morfológicos e influência de tamanho da semente na germinação de jambeiro vermelho. Revista Brasileira de Fruticultura, v.28, n.1, p.117-120, 2006. http://www.scielo.br/pdf/ $\mathrm{rbf} / \mathrm{v} 28 \mathrm{n} 1 / 29706 . \mathrm{pdf}$

DANTAS, B.F.; MATIAS, J.R.; MENDES, R.B.; RIBEIRO, R.C. "As sementes da Caatinga são...": um levantamento das características das sementes da Caatinga. Informativo ABRATES, v.24, n3, p.18-23, 2014.

EMBRAPA - Empresa Brasileira de Pesquisa Agropecuária. Dados meteorológicos da estação agrometeorológica de Bebedouro. Petrolina: Embrapa Semiárido, 2016. <http://www.cpatsa.embrapa.br:8080/ servicos/dadosmet/ceb-mes.html $>$.Accessed on: Dec. $3^{\text {rd }}, 2016$.

FARIA, R.A.P.G.; COELHO, M.D.F.B.; FIGUEIREDO, M.C. Tamanho da semente e sombreamento no desenvolvimento inicial de Brosimum gaudichaudii TRÉCUL. Revista Caatinga, v.26, n.1, p.915, 2013. http://periodicos.ufersa.edu.br/revistas/index.php/sistema/ article/view/2680
FLORES, A.V.; BORGES, E.E.L.; GONÇALVES, J.F.C.; GUIMARÃES, V.M.; ATAIIDE, G.M.; BARROS, D.P.; PEREIRA, M.D. Efeito do substrato, cor e tamanho de sementes na germinação e vigor de Melanoxylon brauna. Pesquisa Florestal Brasileira, v.34, n.78, p.141-147, 2014. http://pfb.cnpf.embrapa.br/pfb/index.php/ $\mathrm{pfb} /$ article/view/558

GARIGLIO, M.A.; SAMPAIO, E.D.S.; CESTARO, L.A.; KAGEYAMA, P.Y. Uso sustentável e conservação dos recursos florestais da caatinga, 2010. 368 p.

GOMES, E.C.S.; BARBOSA, J.; VILAR, F.C.R.; PEREZ, J.O.; VILAR, R.C.; FREIRE, J.L.O.; LIMA, A.N.; DIAS, T.J. Plantas da Caatinga de uso terapêutico: levantamento etnobotânico. Engenharia Ambiental: Pesquisa e Tecnologia, v.5, n.2, 2008. http:// ferramentas.unipinhal.edu.br/engenhariaambiental/viewarticle. php?id $=130 \&$ locale $=$ en

HELLMANN, M.E.; MELLO, J.I.O.; FIGUEIREDO-RIBEIRO R.C.L.; BARBEDO, C.J. Tolerância ao congelamento de sementes de pau-brasil (Caesalpinia echinata Lam.) influenciada pelo teor de água inicial. Revista Brasileira de Botânica, v.29, n.1, p.93-101, 2006. http://www.scielo.br/pdf/rbb/v29n1/a09v29n1

KLEIN, J.; ZUCARELI, V.; KESTRING, D.; CAMILLI, L.; RODRIGUES, J.D. Efeito do tamanho da semente na emergência e desenvolvimento inicial de mudas de pitangueira (Eugenia uniflora L.). Revista Brasileira de Biociências, v.5, n.S2, p.861-863, 2008. http://www.scielo.br/scielo.php?pid=S0102695X2007000100021\&script=sci_arttext

LABOURIAU, L.G. Germinação das sementes. Washington: Secretaria-Geral da Organização dos Estados Americanos, 1983. 174p.

LABOURIAU, L.G.; VALADARES, M.E.B. On the germination of seeds Calotropis procera (Ait.) Ait.f. Anais da Academia Brasileira de Ciências, v.48, n.2, p.263-284, 1976.

LORENZI, H. Árvores brasileiras: manual de identificação e cultivo de plantas arbóreas nativas do Brasil. 3. ed. Nova Odessa: Instituto Plantarum. v.2, 2009. 384 p.

MAGUIRE, J.D. Speed of germination-aid in selection and evaluation of seedling emergence and vigour. Crop Science, v.2, n.1, p.176-177, 1962.

MARCOS-FILHO, J. Fisiologia de sementes de plantas cultivadas. Londrina: ABRATES. 2015. 659p.

MATIAS, J.R.; OLIVEIRA, G.M.; DANTAS, B.F. Colheita e beneficiamento de algumas espécies da caatinga. Informativo ABRATES, v.24, n.3, p.23-27, 2014.

MARTINOTTO, F.; MARTINOTTO, C.; COELHO, M.D.F.B.; AZEVEDO, R.A.B.; FIGUEIREDO, M.C. Sobrevivência e crescimento inicial de espécies arbóreas nativas do cerrado em consórcio com mandioca. Pesquisa Agropecuária Brasileira, v.47, n.1, p.22-29, 2012. http://www.scielo.br/pdf/pab/v47n1/47n01a04.pdf

MARTINS, C.C.; MARTINELLI SENEME, A.; CASTRO, M.M.; NAKAGAWA, J.; CAVARIANI, C. Comparação entre métodos para a avaliação do vigor de lotes de sementes de couve-brócolos (Brassica oleracea L. var. italica Plenk). Revista Brasileira de Sementes, v.24, n.2, p.96-101, 2002. http://www.scielo.br/pdf/rbs/v24n2/v24n2a16 
MEIADO, M.V.; SILVA, F.F.S.; BARBOSA, D.C.A.; SIQUEIRA FILHO, J.A. Diásporos da Caatinga: uma revisão. In: SIQUEIRA FILHO, J.A. (Org.). Flora das Caatingas do Rio São Francisco: História Natural e Conservação. Rio de Janeiro: Andrea Jakobsson, Estúdio Editorial, 2012, p.306-365.

MENDES, R.D.C.; DIAS, D.C.F.S.; PEREIRA, M.D.; DIAS, L.A.S. Testes de vigor para avaliação do potencial fisiológico de sementes de mamona (Ricinus communis L.). Ciência e Agrotecnologia, v.34, n.1, p.114-120, 2010. http://www.scielo.br/scielo. php?pid=S141370542010000100015\&script $=$ sci_abstract\&tlng $=$ pt

MMA - Ministério do Meio Ambiente. Avaliação e ações prioritárias para a conservação da biodiversidade da Caatinga. Brasília: MMA/ SBF, 2002. https://www.conservation.org/global/brasil/publicacoes/ Documents/CAATINGA-EM-PDF01.pdf

MMA/IBAMA -Ministério do Meio Ambiente/Instituto Brasileiro do Meio Ambiente e dos Recursos Naturais Renováveis -. Monitoramento do bioma Caatinga 2008-2009, 2011. 46p. $<$ http:// www.mma.gov.br/estruturas/sbf_chm_rbbio/_arquivos/relatorio_ tecnico_Caatinga_2008_2009_72.pdf>

NAKAGAWA, J. Testes de vigor baseados na avaliação de plântulas. In: KRZYZANOWSKI, F.C.; VIEIRA, R.D.; FRANÇA-NETO, J.B. (Ed.). Vigor de sementes: conceitos e testes. Londrina: ABRATES, 1999.

OLIVEIRA, A.B.; MEDEIROS FILHO, S.; BEZERRA, A.M.E.; BRUNO, R.L.A. Emergência de plântulas de Copernicia hospita Martius em função do tamanho da semente, do substrato e do ambiente. Revista Brasileira de Sementes, v.31, n.1, p.281-287, 2009. http://www.scielo.br/pdf/rbs/v31n1/a31v31n1.pdf

OLIVEIRA, A.K.M.D.; PEREIRA, K.C.L. Temperature effect on the germination and root growth of jatobá-mirim (Guibourtia hymenaefolia (Moric.) J. Léonard) seeds. Ciência Florestal, v. 24, n.1, p.111-116, 2014. http://www.scielo.br/scielo. php?pid $=$ S198050982014000100111\&script $=$ sci_arttext

OLIVEIRA， I.V.D.M.; COSTA， R.S.; ANDRADE， R.A.D.; MARTINS, A.B.G. Influence of the size of the seed on emergence of longan (Dimocarpos longan Lour) seedling. Revista Brasileira de Fruticultura, v.27, n.1, p.171-172, 2005. http://www.scielo.br/scielo. php?pid=S010029452005000100045\&script $=$ sci_arttext\&tlng=es

PÁDUA, G.P.; ZITO, R.K.; ARANTES, N.E.; FRANÇA-NETO, J.B. Influência do tamanho da semente na qualidade fisiológica e na produtividade da cultura da soja. Revista Brasileira de Sementes, v.32, n.3, p. 9-16, 2010. http://dx.doi.org/10.1590/S010131222010000300001

PÁDUA, G.P.; FRANÇA-NETO, J.B.; CARVALHO, M.L.M.; KRZYZANOWSKI, F.C.; GUIMARÃES, R.M. Incidence of green soybean seeds as a fuction of envronmental stresses during seed maturation. Revista Brasileira de Sementes, v.31, n.3, p.150-159, 2009. http://dx.doi.org/10.1590/S0101-31222010000300001

PEREIRA, P.C.; FREITAS, R.S.; MELO, B.; FRANZÃO, A.A. PEREIRA, A.P.; SANTANA, J.G.; LUZ, J.M.Q.; MARTINS, M. Influência do tamanho de sementes na qualidade de mudas de tamarindeiro. Bioscience Journal, v.24, n.4, p.73-79, 2008. http:// www.seer.ufu.br/index.php/biosciencejournal/article/view/6655
PEREIRA, S.R.; GIRALDELLI, G.R.; LAURA, V.A.; SOUZA, A.D. Tamanho de frutos e de sementes e sua influência na germinação de jatobá-do-cerrado (Hymenaea stigonocarpa var. stigonocarpa Mart. ex Hayne, Leguminosae-Caesalpinoideae). Revista Brasileira de Sementes, v.33, n.1, p.141-148, 2011. http://www.scielo.br/scielo. php?script $=$ sci_arttext\&pid=S0101-31222011000100016\&lng=en\& nrm=iso\&tlng $=$ pt

REGO, S.S.; FERREIRA, M.M.; NOGUEIRA, A.C.; GROSSI, F. Influência de potenciais osmóticos na germinação de sementes de Anadenanthera colubrina (Veloso) Brenan (Angico-branco) Mimosaceae. Revista Brasileira de Biociências, v.5, p.549-51, 2007. http://www.ufrgs.br/seerbio/ojs/index.php/rbb/article/viewFile/484/421

REIS, R.D.G.E.; BEZERRA, A.M.E.; GONÇALVES, N.R.; PEREIRA, M.S.; FREITAS, J.B.S. Biometria e efeito da temperatura e tamanho das sementes na protrusão do pecíolo cotiledonar de carnaúba. Revista Ciência Agronômica, v.41, n.1, p.81-86, 2010. http://ccarevista.ufc.br/seer/index.php/ccarevista/article/view/459

ROBERTS, E.H. Predicting the storage life of seeds. Seed Science and Technology, v.1, p.499-514, 1973.

SANTOS, H.R.B.; RIBEIRO, M.S.; MEDEIROS, D.B.; NOGUEIRA, R.J.M.C. Morfometria de sementes de pinhão manso (Jatropha curcas L.). Scientia Plena, v.8, n.4, 2012. http://www. scientiaplena.org.br/sp/article/view/1021

SILVA, B.M.D.S.; CARVALHO, N.M.D. Efeitos do estresse hídrico sobre o desempenho germinativo da semente de faveira (Clitoria fairchildiana RA Howard. - Fabaceae) de diferentes tamanhos. Revista Brasileira de Sementes, v.30, n.1, p.55-65, 2008. http:// www.scielo.br/pdf/rbs/v30n1/a08v30n1

SILVA, E.M.; ANDRADE, E.M.G.; DANTAS, E.A.; LACERDA, R. R.A.; LOPES, K. P. Diagnóstico do uso de leguminosas em propriedades rurais no município de Aparecida-PB. Revista Verde de Agroecologia e Desenvolvimento Sustentável, v.7, n.3, p.212-217, 2012(a). http://www.gvaa.org.br/revista/index.php/RVADS/article/ viewArticle/1765.

SILVA, K.B. Qualidade fisiológica de sementes de Sideroxylon obtusifolium (Roem. \& Schult.) Penn. classificadas pelo tamanho. Revista Brasileira de Biociências, v.13, n.1, p.1-4, 2015. http://www. ufrgs.br/seerbio/ojs/index.php/rbb/article/view/2553

SILVA, K.S.; MENDONÇA, V.; MEDEIROS, L.F.; CASTRO FREITAS, P.S.; GÓIS, G.B. Influência do tamanho da semente na germinação e vigor de mudas de jaqueira (Artocarpus heterophyllus Lam.). Revista Verde de Agroecologia e Desenvolvimento Sustentável, v.5, n.4, p.217-221, 2010. http://www.gvaa.com.br/ revista/index.php/RVADS/article/view/359/392

SILVA, N.C.B.; REGIS, A.C.D.; ESQUIBEL, M.A.; SANTOS, J.E.S.; ALMEIDA, M.Z.A. Uso de plantas medicinais na comunidade quilombola da Barra II-Bahia, Brasil. Boletín Latinoamericano y del Caribe de Plantas Medicinales y Aromáticas, v.11, n.5, p.435-453, 2012(b). http://www.revistaidea.usach.cl/ojs/index.php/blacpma/ article/download/913/865

VIEIRA, R.D.; CARVALHO, N.M. (Eds.) Testes de vigor em sementes. Jaboticabal: FUNEP, 1994. 164p. 
VILE, D.; PERVENT, M.; BELLUAU, M.; VASSEUR, F.; BRESSON, J.; MULLER, B.; GRANIER, C.; SIMONNEAU, T. Arabidopsis growth under prolonged high temperature and water deficit: independent or interactive effects?. Plant, cell \& environment, v. 35, n. 4, p.702-718, 2012. http://onlinelibrary.wiley. com/doi/10.1111/j.1365-3040.2011.02445.x/full

WAGNER JÚNIOR, A.; COSTA, J.O.; SILVA, L. D. P.; SANTOS, C. E. M.; BRUCKNER, C. H. Germinação e desenvolvimento inicial de duas espécies de jabuticabeira em função do tamanho de sementes. Acta Scientiarum. Agronomy, v.33, n.1, p.105-109, 2011. http://www.scielo.br/pdf/asagr/v33n1/v33n1a15.pdf
WEBER, C.R.; SOARES, C.M.; LOPES, A.B.; SILVA, T.S.; NASCIMENTO, M.S.; XIMENES, E.C. Anadenanthera colubrina: um estudo do potencial terapêutico. Revista Brasileira de Farmácia, v. 92, n. 4, p. 235-244, 2011. http://rbfarma.org.br/files/rbf-2011-924-1-235-244.pdf

ZAMAN-ALLAH, M.; JENKINSON, D. M.; VADEZ, V. Chickpea genotypes contrasting for seed yield under terminal drought stress in the field differ for traits related to the control of water use. Functional Plant Biology, v. 38, n. 4, p. 270-281, 2011. https://doi.org/10.1071/FP10244 